\author{
Jan Macuda*, Łukasz Łukańko*
}

\title{
MONITORING OF EXPLOSIVE GASES WITH A PORTABLE GAS DETECTOR DRÄGER X-AM 5600**
}

\section{INTRODUCTION}

Oil and gas industry covers the whole spectrum of activities, starting from hydrocarbon prospecting, extraction of oil and natural gas, and finally their transport and storing. The presence of volatile hydrocarbons in the installation creates a serious danger of an explosion; if contaminated with hydrogen sulfide, they are also dangerous for the health and life of the crew.

For the sake of lowering this hazard, the crew performing their duties in the zones threatened with methane outburst and hydrogen sulfide contamination should be equipped with portable gas detectors which automatically notify about the hazardous situation with an alarm signal. Among such utilities are portable gas detector Dräger X-am 5600, which may simultaneously measure the concentration of six different gases in air, methane and hydrogen sulfide including [1]. This detector has been granted the ATEX certification, i.e. the device can be used in areas threatened with explosion classified as zone 0 . In zone 0 the explosive mixture may be generated constantly or periodically, and they contain flammable substances in the form of gases, vapors and mist.

\section{HAZARD ASSOCIATED WITH HYDROCARBON DEPOSITS PROSPECTING AND EXTRACTION}

Explosion hazard generated during hydrocarbon prospecting and then extraction are connected with the explosiveness of the gas-air mixture. One of the gases which may

* AGH University of Science and Technology, Faculty of Drilling, Oil and Gas, Krakow, Poland

** This study was supported by the National Center for Research and Development, Grant: Blue Gas - Polish Shale Gas, Agreement No. BG1/EKO ŁUPKI/13 
be present during these jobs and which is hazardous for the health and life of people is methane [11].

Methane belongs to flammable gases reacting with oxygen, in the course of which flame and great amounts of heat are produced. Methane is ignited in the presence of an ignition initiator, e.g. electric spark or flame. When the methane concentration in air is between the lower and upper explosive limit, the combustion has an explosive character. The explosive limits, expressed by methane content in the mixture with air, in temperature of $20^{\circ} \mathrm{C}$ and pressure of 1 bar are [5]:

- $5 \% \mathrm{v} / \mathrm{v}$ methane - lower explosive limit,

- $15 \% \mathrm{v} / \mathrm{v}$ methane - upper explosive limit.

The ignition of methane may take place without the participation of external initiator if the temperature of the methane/air mixture reaches $537^{\circ} \mathrm{C}$ at a pressure of 1 bar [5].

Methane is not considered to be toxic. In high concentrations it acts like choking gas, displacing oxygen. Among the symptoms of methane contamination are the loss of mobility and even loss of consciousness [5, 6]. The crew may be not aware of the asphyxiation processes as in low concentrations methane may bring about narcotic effects, e.g. dizziness and headache, nausea and loss of coordination of movements.

Another gas which may appear in air in the course of exploration and extraction of hydrocarbons is hydrogen sulfide. This gas is both toxic and explosive; after exceeding the admissible level it may have a negative impact on the health and lives of the crew [5].

Hydrogen sulfide is a colorless gas of characteristic sweet smell of rotten eggs (odor threshold of $0.18 \mathrm{mg} / \mathrm{m}^{3}$ ) [12]. This gas can be easily absorbed by the organism to the lungs and to a lesser degree through the skin. In lower concentrations the irritation of the conjunctiva and of the respiratory system can be observed; when the concentration ranges between 1400 to $2800 \mathrm{mg} / \mathrm{m}^{3}$ the respiratory system is irritated and the breathing processes stopped [12]. Hydrogen sulfide is also a flammable gas and its lower and upper explosive limits equal to $4.3 \% \mathrm{v} / \mathrm{v}$ and $45 \% \mathrm{v} / \mathrm{v}$, respectively [12]. Hydrogen sulfide can self-ignite when the mixture of air and hydrogen sulfide reaches temperature of $290^{\circ} \mathrm{C}$ [12].

\section{CHARACTERISTIC OF PORTABLE GAS DETECTOR DRÄGER X-AM 5600}

The portable gas detector Dräger X-am 5600 is equipped with two types of sensors, i.e. infrared sensors and electrochemical sensors [1]. Thanks to the applied infrared technology and miniature electrochemical sensors for the measurement of gas concentration, Dräger XXS may monitor 6 types of gases simultaneously [1]. The sensor can be configured in the device, depending on needs. 
The principle of IR sensors lies in the absorbed radiation by hydrocarbons in the wavelength range corresponding to that of infrared [3]. An IR emitter is installed inside the sensor. It emits waves, which are reflected and directed to the detector. The gaseous mixture passes through the flame arrestor into the sensor. The major air components, i.e. oxygen and nitrogen do not absorb the radiation on the detector as far as infrared is concerned, and the intensity or radiation on the detector may be weakened only in the presence of hydrocarbons. If so, an electrical signal is emitted, and it is transmitted to the display of the measuring device, e.g. 0-100 vol.\% of gas or \% of lower explosive limit. The principle of measurement of explosive gases concentration in an infrared sensor is presented in Figure 1.
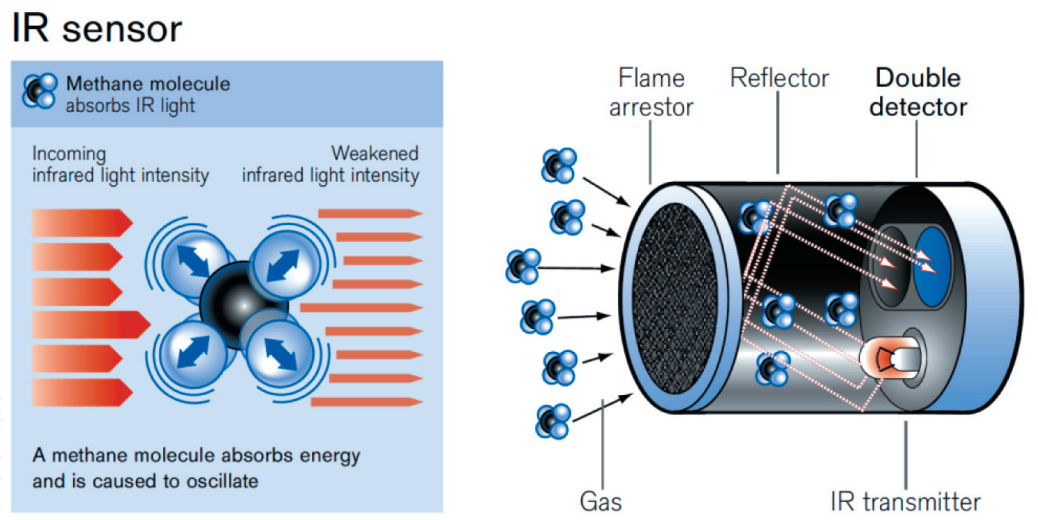

Fig. 1. Principle of infrared sensors in Dräger X-am 5600 [4]

Electrochemical sensors are microreactors generating a small current in the presence of reactive gases [3]. It consists of at least two electrodes - measuring electrode and counter electrode. They are connected in two ways: on one hand by the electrolyte (fluid conducting ions), and on the other one, by external electrical circuit [3]. Gas inflows through a porous membrane to the sensor filled with the electrolyte, and current is generated between the electrodes. The intensity of measured current is transmitted to the gas concentration display in the detector [3]. The principle of electrochemical sensors installed in Dräger X-am 5600 is presented in Figure 2.

The infrared sensors IR Ex in the gas detector Dräger X-am 5600 are used for measuring the concentration of carbon dioxide and explosive gases, e.g. methane, propane and ethylene. The IR Ex sensor allows for measuring the concentration of methane both within the lower and upper explosive limit, and also in the range 0 to 100 vol.\% with the accuracy of 0.01 vol.\% [3]. The IR $\mathrm{CO}_{2}$ for measuring the carbon dioxide concentration can be used for measurements in the range of 0 to 5 vol. $\%$ of $\mathrm{CO}_{2}$ in air [3]. The gas detector in Dräger X-am 5600 is presented in Figure 3. 


\section{Electrochemical sensor}

\begin{tabular}{|c|c|}
\hline (c) & $\begin{array}{l}\text { CO-Molecule } \\
\text { Target gas, enters into the } \\
\text { measuring electrode }\end{array}$ \\
\hline & $\begin{array}{l}\mathrm{CO}_{2} \text {-Molecule } \\
\text { Reaction product, leaves } \\
\text { the measuring electrode }\end{array}$ \\
\hline & $\begin{array}{l}\mathrm{H}_{2} \mathrm{O} \text {-Molecule } \\
\text { part of the electrolyte }\end{array}$ \\
\hline$\epsilon$ & $\begin{array}{l}\mathrm{H}^{+} \text {Hydrogen-lon } \\
\text { positive charge (because } \\
\text { one electron is missing) }\end{array}$ \\
\hline & Oxygen atom \\
\hline & $\begin{array}{l}\text { Oxygen-Molecule } \\
\text { from the ambient air }\end{array}$ \\
\hline$\Theta$ & Electron \\
\hline
\end{tabular}

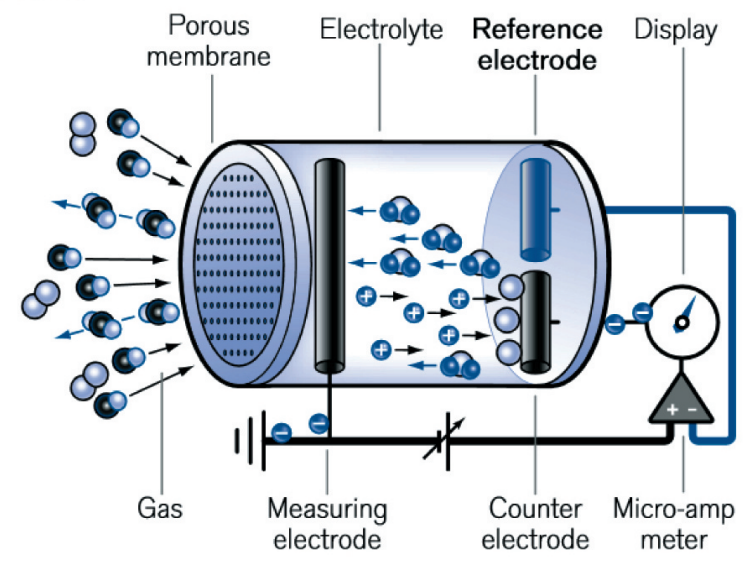

Chemical reaction at the measuring electrode

$\mathrm{CO}+\mathrm{H}_{2} \mathrm{O} \rightarrow \mathrm{CO}_{2}+2 \mathrm{H}^{+}+2 \mathrm{e}^{-}$

Chemical reaction at the counter electrode

$1 / 2 \mathrm{O}_{2}+2 \mathrm{H}^{+}+2 \mathrm{e}^{-} \rightarrow \mathrm{H}_{2} \mathrm{O}$

Fig. 2. Principle of electrochemical sensors in Dräger X-am 5600 [4]

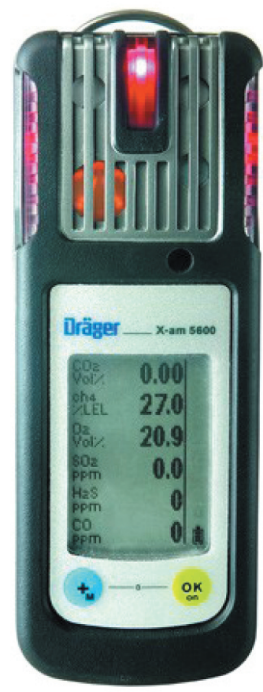

Fig. 3. Gas detector in Dräger X-am 5600 [1]

\section{APPLICATION OF PORTABLE GAS DETECTOR DRÄGER X-AM 5600 FOR MONITORING AIR IN OIL AND GAS INDUSTRY}

According to the Polish law, the work stands, where the crew handles substances classified as hazardous for human health or life or substances creating fire or explo- 
sion hazard, should be labeled and appropriately protected [8-10, 12]. When different jobs are realized, when the hazard is observed for a relatively short time, the use of a permanent monitoring system seems to be inefficient, especially in view of economics. This type of monitoring can be successfully performed with a portable gas detector Dräger X-am 5600 with the station Dräger X-zone 5500. After configuring, these devices may efficiently monitor the zones where the health and life of crew can be threatened. The station Dräger X-zone 5500 is presented in Figure 4.

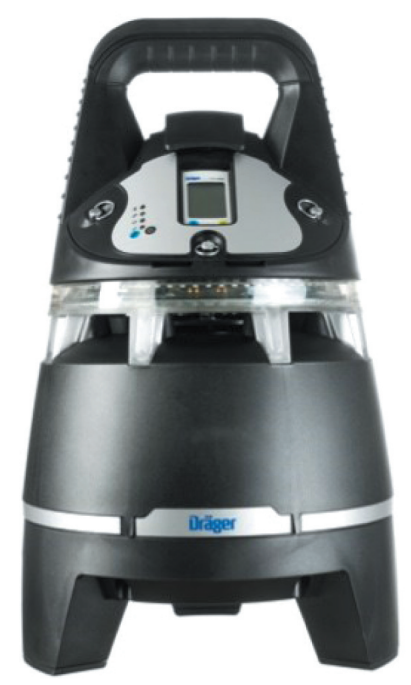

Fig. 4. Station Dräger X-zone 5500 with gas detector Dräger X-am 5600 [2]

Dräger X-zone 5500 stations can be arranged in a safety line consisting of even 25 devices [2]. This type of array can be used for making safety networks protecting larger areas, e.g. rigs or oil and gas wells. After detecting a gas hazard, Dräger X-zone 5500 alarms all units in the safety line. The blinking red alarm in the gas detector contrasts with the blinking red and green lights of the interconnected devices. In this way the alarm situation can be monitored and the danger localized. Properly configured, this device also displays the maximum gas concentration in the monitored area. Additionally, Dräger X-zone has a module providing for a remote access to the data of the detector in the station (GSM) [2]. Thanks to this the information about hazard can be automatically sent to the controller. Moreover, all pieces of information are periodically e-mailed or saved on a FTP server or in cloud [2].

Equipped with a measuring probe $\mathrm{X}$-am 125, the gas detector Dräger X-am 5600 can detect leaks in the gas pipelines or storages of explosive and toxic gases [1]. 


\section{ANALYSIS OF METHANE EMISSION DURING GAS WELL TUBING}

During off gas well venting operations, methane is emitted from the reservoir water tank to the atmosphere (in various concentrations). There is a potential hazard that the lower explosive limit will be exceeded. For the sake of evaluating the degree of hazard, the methane concentration was measured in the closest vicinity of the tank. The first measurement point was located where the separated brine was outflowing from the pipeline to the tank, while the second point was at other side of the tank. In first point, the following measurements were performed: $\mathrm{CH}_{4}, \mathrm{O}_{2}, \mathrm{CO}_{2}, \mathrm{H}_{2} \mathrm{~S}$ and $\mathrm{NO}_{x}$, while at the second point, only methane concentration was measured. A series of measurements was performed in the study area with the use of the portable gas detector Dräger X-am 5600 .

The obtained results are presented in Table 1, where in column 2, methane concentration in first measurement point are presented, in column 3 results from the second point.

Table 1

List of results of concentration of gases emitted from reservoir water during the test tubing

\begin{tabular}{|c|c|c|c|c|c|c|}
\hline \multirow{2}{*}{ No. } & \multicolumn{7}{|c|}{ Type of measured gas } & \multicolumn{2}{c|}{$\begin{array}{c}\mathrm{CH}_{4} \\
\%\end{array}$} & \multicolumn{2}{|c|}{} & $\begin{array}{c}\mathrm{H}_{2} \mathrm{~S} \\
\mathrm{ppm}\end{array}$ & $\begin{array}{c}\mathrm{CO}_{2} \\
\%\end{array}$ & $\begin{array}{c}\mathrm{NO}_{x} \\
\mathrm{ppm}\end{array}$ \\
\cline { 2 - 7 } & 1.05 & 0.12 & 20.23 & 2 & 0.12 & 1 \\
\hline 1 & 0.58 & 0.07 & 20.08 & 2 & 0.09 & 1 \\
\hline 2 & 1.42 & 0.16 & 20.18 & 1 & 0.08 & 3 \\
\hline 3 & 0.39 & 0.10 & 20.92 & 3 & 0.08 & 2 \\
\hline 4 & 0.19 & 0.03 & 20.71 & 3 & 0.11 & 1 \\
\hline 5 & 0.27 & 0.02 & 20.82 & 3 & 0.09 & 0 \\
\hline 6 & 0.51 & 0.04 & 20.74 & 2 & 0.12 & 1 \\
\hline 7 & 0.72 & 0.05 & 20.73 & 2 & 0.15 & 1 \\
\hline 8 & 0.18 & 0.03 & 20.85 & 1 & 0.11 & 2 \\
\hline 9 & 0.73 & 0.07 & 20.76 & 1 & 0.08 & 1 \\
\hline 10 & 0.57 & 0.05 & 20.74 & 3 & 0.06 & 1 \\
\hline 11 & 0.72 & 0.07 & 20.81 & 3 & 0.24 & 1 \\
\hline 12 & 0.46 & 0.06 & 20.83 & 2 & 0.07 & 0 \\
\hline 13 & 0.34 & 0.03 & 20.22 & 2 & 0.13 & 2 \\
\hline 14 & 1.05 & 0.12 & 20.79 & 3 & 0.12 & 1 \\
\hline 15 & 0.81 & 0.07 & 20.82 & 3 & 0.12 & 2 \\
\hline 16 & 0.38 & 0.05 & 20.89 & 3 & 0.07 & 2 \\
\hline 17 & 0.62 & 0.04 & 20.78 & 2 & 0.06 & 1 \\
\hline 18 & & & & & & \\
\hline
\end{tabular}


After analyzing the obtained data, it was observed that a much higher concentration of methane in the atmosphere was detected in the first measuring point, from 0.18 to $1.42 \%$ (Fig. 5 ).

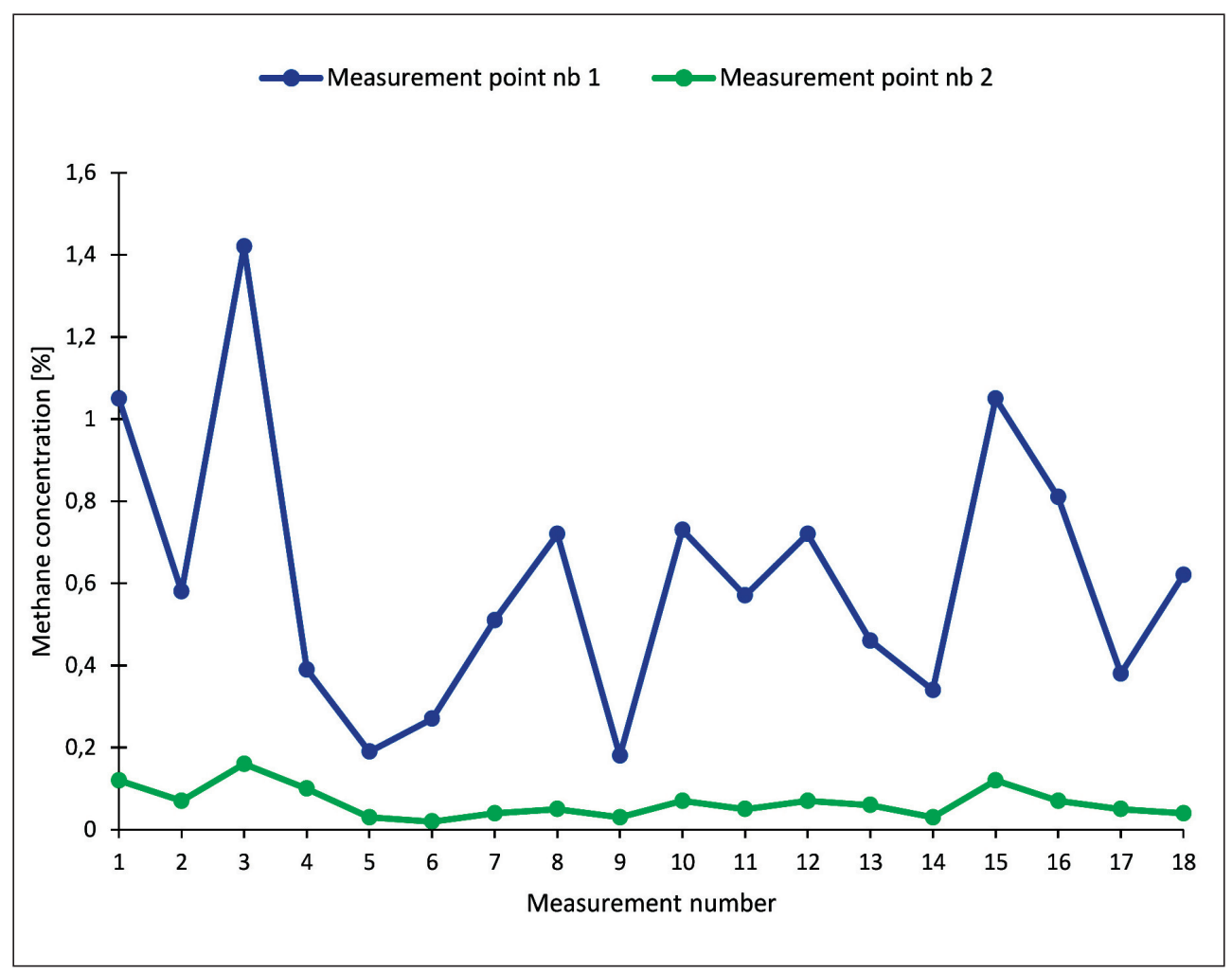

Fig. 5. Results of methane concentration measurements

Methane concentration was below the lower explosive limit, however, in unfavorable weather conditions (lack of wind) or when gas flow will be near-maximum capacity of the separator, the concentration of methane can exceed the lower explosion limit. Therefore, the outflow zone of the brine from the pipeline to the water tank should be classified as explosion zone 1.

Hydrogen sulphide concentrations were also measured at this point. The measured concentrations were very low, from 1 to 3 ppm (Fig. 6) as well as the concentration of $\mathrm{NO}_{x}$ (Tab. 1 column 7).

At the second measurement point, the concentration of methane was significantly lower than at point 1 , ranged from 0.02 to $0.16 \%$ (Tab. 1, column 3 ). 


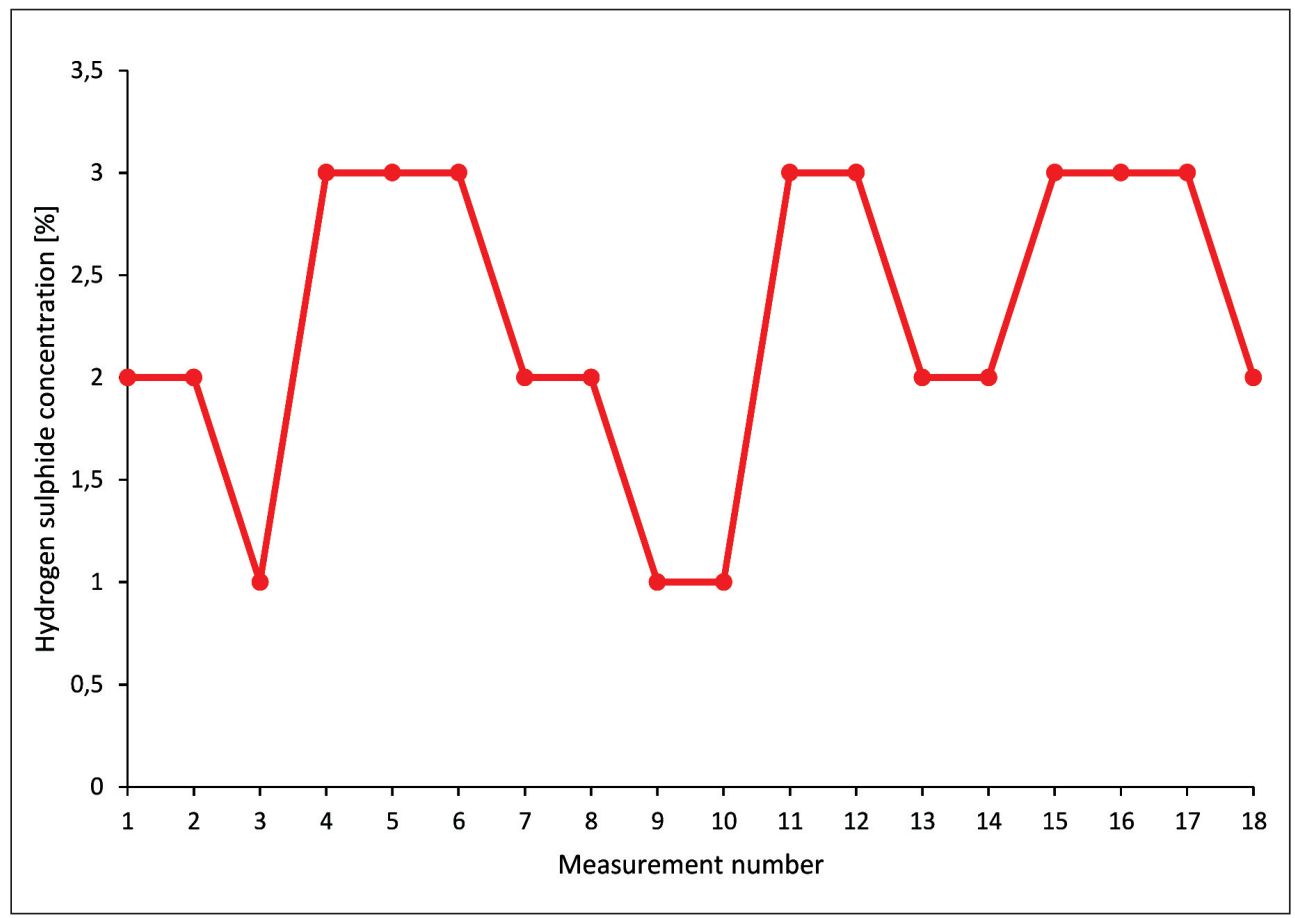

Fig. 6. Results of hydrogen sulphide concentration measurements

\section{CONCLUSIONS}

1. Portable gas detector Dräger X-am 5600 can be successfully used for detecting explosive and toxic gases, and for monitoring in explosive zone 0 while performing exploration and extraction of hydrocarbons.

2. Thanks to the fact that Dräger $\mathrm{X}$-am 5600 can detect 6 gases simultaneously, this device can be broadly used in oil and gas industry for periodical or constant monitoring of explosive and toxic gases.

3. Owing to its technical parameters, the analyzer can be especially used for periodical monitoring of explosive gases while performing production tests in exploration wells, production wells and during repairs of the industrial installations for the extraction and distribution of hydrocarbons.

4. Thanks to the built-in GSM module in the station Dräger X-zone, the conditions in the place of work can be remotely observed by the controllers.

5. Potential methane explosion hazard during gas well tubing operation may occur at the outflow point of the brine to the tank. 


\section{REFERENCES}

[1] Dräger: Gas detection instruments. Dräger X-am ${ }^{\circledR}$ 5600, Germany 2016.

[2] Dräger: Gas detection instruments. Dräger X-zone 5500, Germany 2016.

[3] Dräger: Wstęp do systemów detekcji gazowej. Dräger. Technika dla życia. 2016

[4] Dräger's Guide to Portable Gas Detection. Germany 2012

[5] Krawczyk M.: Wybuchowość mieszanin gazowych. Materiały dydaktyczne, Gdańsk 2003.

[6] Linde Group: Karta charakterystyki metanu. 2013.

[7] Macuda J., Zawisza L.: Występowanie metanu w złożu węgla brunatnego KWB Betchatów S.A. Wiertnictwo Nafta Gaz, vol. 22, No.1, 2005, pp. 233-238.

[8] Obwieszczenie Ministra Gospodarki, Pracy i Polityki Społecznej z dnia 28 sierpnia 2003 r. w sprawie ogłoszenia jednolitego tekstu rozporzadzenia Ministra Pracy i Polityki Socjalnej w sprawie ogólnych przepisów bezpieczeństwa i higieny pracy. Dz. U. 2003 nr 169 poz. 1650.

[9] Rozporzadzenie Ministra Gospodarki z dnia 8 lipca 2010 r.w sprawie minimalnych wymagań, dotyczących bezpieczeństwa i higieny pracy, związanych z możliwościa wystapienia w miejscu pracy atmosfery wybuchowej. Dz. U. 2010 nr 138 poz. 931.

[10] Rozporzadzenie Ministra Gospodarki z dnia 25 kwietnia 2014 r. w sprawie szczegółowych wymagań dotyczących prowadzenia ruchu zakładów górniczych wydobywajacych kopaliny otworami wiertniczymi. Dz. U. 2014 poz. 812.

[11] Solecki T., Macuda J.: Metody wykrywania i identyfikacji substancji ropopochodnych w środowisku gruntowo-wodnym. Wiertnictwo Nafta Gaz, vol. 21, No. 1, 2004, pp. 325-332.

[12] Stetkiewicz J.: Siarkowodór. Dokumentacja dopuszczalnych wielkości narażenia zawodowego. Podstawy i Metody Oceny Środowiska Pracy, 4(70), 2011, pp. 97-117. 